\title{
Impact of Transport Infrastructure on Gross Regional Products: Evidence from Chinese Provinces under the "Belt and Road Initiative"
}

\author{
Jin-Hui Li ${ }^{1}$, Chol-Ju An ${ }^{2}$ \& Gwang-Nam Rim ${ }^{3 *}$ \\ ${ }^{1}$ Doctor. Research Fellow, Center for North and South Korea Studies, Yanbian University, Yanji, Jilin, China \\ ${ }^{2}$ Professor, Doctor, Foreign Trade Department, Faculty of Economics, Kim II Sung University, Pyongyang, Democratic People's \\ Republic of Korea \\ Distinguished Researcher of the Center for North and South Korea Studies, Yanbian University, Yanji, Jilin, China \\ ${ }^{3}$ Professor, Doctor, Statistics Department, Faculty of Economics, Kim II Sung University, Pyongyang, Democratic People's \\ Republic of Korea \\ Distinguished Researcher of the Center for North and South Korea Studies, Yanbian University, Yanji, Jilin, China \\ *Corresponding Author: kwangnam@126.com or gn.rim@ryongnamsan.edu.kp
}

DOI: https://doi.org/10.38157/business-perspective-review.v2i2.145

Citation: Li, J., An, C. \& Rim, G. (2020). Impact of Transport Infrastructure on Gross Regional Products: Evidence from Chinese Provinces under "Belt and Road" Initiative. Business Perspective Review 2(2), 23-45. DOI: https://doi.org/10.38157/businessperspective-review.v2i2.145

\section{Research Article}

\section{Abstract}

Purpose: This paper analyzes the impact of transport infrastructure on Gross Regional Products in Chinese provinces under the "Belt and Road Initiative".

Methods: The impact of the key elements of transport infrastructure on Gross Regional Products is analyzed based on the data related to development levels of transport infrastructure and economic development. Correlation and regression analyses were used for data analysis.

Results: It is found that railways and highways, which are the key elements of transport infrastructure, have a strong correlation with Gross Regional Products, and their effects are diverse among provinces under study.

Implications: The findings demonstrate the position and role of diverse infrastructural elements in enhancing the economic benefits of infrastructural investment and promoting economic growth. Thus, it is expected to facilitate decision-making related to infrastructural investment under the "Belt and Road Initiative".

Keywords: Transport Infrastructure (TI); Gross Regional Products (GRP); Belt and Road Initiative (BRI); Chinese Economy.

\section{Introduction}

In 2013, China proposed the "Belt and Road Initiative" (BRI or OBOR) composed of Land Road "Silk Road Economic Belt" and Sea Road "21st-Century Maritime Silk Road". Now the initiative is carried forward seriously. The BRI aims to increase the integration among countries in Asia as 
well as in Africa and Europe, but it is essential for promoting the economic growth and further ensuring sustainable economic development in China (National Development and Reform Commission et al., 2015a). The objectives of BRI includes regional development as well as development of Chinese industry. Peter (2017a) says that the regional development aspect of BRI is one of China's most important economic policy objectives. According to him/her, if the Chinese Government fails to connect its domestic projects with overseas components through BRI, it will greatly diminish its economic and strategic value. In 2014, BRI was officially incorporated into China's national economic development strategy at the Central Economic Work Conference, and China announced three regional development plans, one of which was BRI. Thus, these regional development plans are designed to address the chronic problem of uneven development in China (Yifei, 2016). Inequality between inland western regions and prosperous eastern seaboard states is a huge challenge for China. For example, the coastal mega-metropolis of Shanghai is five times wealthier than the inland province of Gansu, which is part of the old Silk Road (The Economist, 2016). Also, the western regions of Xinjiang, Tibet, Qinghai, and Gansu are the four lowest-ranked provinces on the China Economic Research Institute's Free Market Index (Xiaolu, et al. 2016).

The key area in BRI is the infrastructural connectivity, and transport infrastructure (TI) will be a particular focus (Haggai, 2016). TI will stimulate economic growth in China and affect the majority of the Chinese provinces. In particular, some of the Chinese provinces will be directly affected by the initiative, since the New Silk Roads will go through these provinces. Youqing (2015) estimates all provinces have earmarked just over a trillion renminbi for BRI-related infrastructure projects; 68 percent of them will be related to railway, road, and airports. He estimates this will add 0.2 to 0.3 percentage points to China's GDP growth, although this estimate needs to be treated with a degree of caution. On the other hand, China focuses on exporting its technological standards to become an innovation-based economy and a leader in research and development (Peter, 2017b). This shows that China focuses on infrastructure connectivity, on the one hand, in western inland provinces to ensure the regional development of underdeveloped regions, and on the other hand, in coastal provinces to upgrade the Chinese economy.

However, it is seen that there is little success in studies on the impact of infrastructural projects on the Chinese provinces under BRI. The scholar who relatively comprehensively analyzed the impact of under BRI on the Chinese Gross Domestic Products (GDP) is Ylander (2017a). However, he/she did not study the impact of infrastructure on GRP in specific provinces directly affecting by BRI. This study is based on what is of significance in BRI is infrastructural connectivity and infrastructure has a positive effect on economic growth. This will probably give the significant implications for strategic management in infrastructural investment under BRI. Furthermore, in Chinese provinces where are the major routes under BRI, it can say that analyzing the impacts of TI's elements on GRP is of great significance in evaluating the efficiency of infrastructural projects under BRI, and in realizing infrastructural investment in keeping with the requirements of regional economic development and improvement in given provinces. From the significances of our studies, the paper aims to analyze the impact of 
railways and highways on GRP in the Chinese provinces directly affecting by BRI. Based on the research purpose, this paper is organized as follows. In the second section, the authors discuss previous studies related to the impact of infrastructure on economic development. In the third section, the authors deal with the correlation of railways and highways with GRP and construct the regression models, and conducts forecasts using the data from 2009 to 2017. The rest of the paper addresses the results, discussions, conclusion, limitations, and future research.

\section{Previous studies on the impact of infrastructure on economic development}

Previous researchers analyzed the effects of infrastructural investment on economic development using various methods. Representatively, Aschauer (1989) estimated that elasticity of output concerning public investment in infrastructure was between 0.34 and 0.39 . Some authors proved the strong positive impact of public capital in the international or regional level using the production function approach (for example, Bajo \& Sosvilla, 1993 for Spain; Ligthart, 2002 for Portugal; Otto \& Voss, 1994, 1996 for Australia and the like), and others analyzed the productivity of infrastructural investment using the cost function approach (Berndt and Hansson, 1992; Demetriades \& Mamuneas, 2000). Also, some authors proved the positive impact of public capital on output in some countries using Vector Auto Regression (VAR) approach (for example, Mamatzakis, 1999 for Greece; Pereira \& Roca, 1999 for Spain and the like). In industry level, many scholars showed the positive effect of infrastructure on economic performance using production function approach (Costa et al., 1987; Fernald. 1993, 1999; Greenstein \& Spillar, 1995; Pinnoi, 1992), cost function approach (Nadiri \& Manuneas,1994, 1996) and VAR approach (Pereira and Andraz, 2003).

In some studies, the influences of the individual elements of infrastructure on economic development were illustrated. Some researchers revealed the positive impact of energy infrastructure on economic growth (Dethier et al. 2008; Garsous 2012) and others analyzed the impact of water and sanitation on economic performance (Binswanger et al. 1992; Estache et al. 2005). And researchers discussed the impact of telecommunication infrastructure on economic growth (for example, Zhan-Wei Qiang \& Pitt 2004; Chakraborty \& Nandi 2011) and studied the impact of TI on the economy in various aspects (for example, Buys et al. 2006; Estache-Fay 2010; Wilson et. al 2003). Also, Pereira \& Andraz (2011) demonstrated the positive impact of infrastructural investment on economic development through the analysis of previous studies.

Scholars in China and various countries discussed the impact of infrastructure on economic development in China. Ni (2013) studied the impact of TI investment on economic growth in China and judged that there was long-term stable equilibrium relationship between TI and economic performance, and the TI's positive spillovers to economic growth. Yingying et al. (2017) examined the relationship between infrastructural capital and China's GRP for the period 1990-2013 and using a vector error correction model, found the support for the contribution of infrastructural investment to economic development. Xinmin et al. (2017) investigated the impact of TI investment on economic growth in China and revealed that TI investment had a positive impact on economic growth with a contribution rate of $12 \%$. Ylander (2017b) conducted the regression analysis using various variables including TI's elements, unemployment rate, 
labor productivity, and exports which affect the GRP to show how BRI and its infrastructural projects affect the GRP in China. According to him/her, BRI has a positive impact on GRP in Chinese provinces under BRI. Besides, discussing the focus areas for executing the BRI, some scholars mentioned the infrastructural connectivity as an important item. As seen above, since BRI is in an early stage for its execution, there exists a little study on its impact on China's regional economic development, in particular, the impact of TI under BRI.

This paper focuses on analyzing the impact of TI on China's GRP under BRI, and thus, based on the research of Ylander (2017), discusses the influences of railways and highways on regional economic growth in the Chinese provinces directly affected by BRI.

\section{Data and methods}

\subsection{Processing of data}

According to the National Development and Reform Commission et al. (2015b), BRI will have a direct effect on ten Chinese provinces since the route under BRI will go through these provinces. Under BRI, the inland route will go through Shaanxi, Gansu, Ningxia Autonomous Region (Hereafter, Ningxia), Qinghai, and Xinjiang Uygur Autonomous Region (Hereafter, Xinjiang), and the maritime road will be connected with ports in Zhejiang, Fujian, Guangdong, Guangxi Autonomous Region (Hereafter, Guangxi), and Hainan. Of course, at present, in addition to these provinces, other provinces participate in BRI, and they have their infrastructural projects related to BRI. However, these provinces are not initiating routs under BRI, and are of significance in connecting with ten provinces abovementioned. In particular, linking the western provinces such as Shaanxi, Gansu, Ningxia, Qinghai, and Xinjiang with neighboring countries, thus stimulating the economic development of these provinces is one of the major objectives for BRI. And due to the unavailability of data, it is difficult to separate BRI projects from whole projects in these provinces, and thus, it is assumed that all infrastructural projects are related to BRI. Also, on the other hand, this study is aimed to estimate the impact of future TI projects on GRP in these provinces. Therefore, authors analyze based on data related to development levels of, on the one hand, TI elements such as railways and highways, and on the other hand, regional economic growth from 2009 to 2017 for ten Chinese provinces directly affecting by BRI. Authors selected data regarding the physical TI's elements because the infrastructural investment is no basis for economic development in a given period due to time lags, investment per a unit of TI elements is different due to regional features of given provinces, and the data of physical infrastructure are accessible to the database.

Under the above precondition related to the collection of primary data, authors collected the primary data regarding GRP, population, area, length of railways in operation, and length of highways for ten provinces directly affecting by BRI. Explanations about primary data are as follows; GRP refers to the final products at market prices produced by all resident units in a region (or province in this study) during a certain period, that is, regional GDP.

Furthermore, authors use relative values, not absolute values regarding all data to ensure the comparability among provinces under study. For an in-depth study, this paper aims to analyze the relationship between the development level of TI and GRP in Chinese provinces, and thus, it ensures 
the comparability among provinces which is of much significance. In general, previous studies did not consider region-specific features from the purpose of studying the whole TI and GRP, and thus, they did not bring forward the issue of ensuring the comparability among provinces. This led to the wrong conclusion that the larger the absolute value of individual TI is, the higher the development level of a certain region is. This means that the magnitude of provinces under study should be considered in the analysis to ensure comparability. From this, authors will use indicators such as GRP per capita, density of railways $(\mathrm{km} / 1000 \mathrm{~km})$, and the density of highways $\left.(\mathrm{km} / 1000 \mathrm{~km})^{2}\right)$ as they reflect economic development level and TI's development level (Li, et al. 2020). The density of railways ( $\mathrm{km} / 1000 \mathrm{~km})$ is value divided the length of railways in operation by area of the given province and multiplied by 1000 , and the density of highways $\left.(\mathrm{km} / 1000 \mathrm{~km})^{2}\right)$ - one divided the length of railways in operation by area of the given province, and multiplied by 1000 . GRP per capita is value divided GRP by the number of populations of the given province. Tables 1 and 2 describe the economic development level (GRP per capita) and TI's development level (Densities of railways and highways) according to provinces and years.

Table 1. Province- and year- specific GRP per capita and densities of railways and highways (Inland provinces)

\begin{tabular}{|c|c|c|c|c|c|c|c|c|c|c|}
\hline \multirow{2}{*}{ Province } & \multirow{2}{*}{ Indicator } & \multicolumn{9}{|c|}{ Year } \\
\hline & & 2009 & 2010 & 2011 & 2012 & 2013 & 2014 & 2015 & 2016 & 2017 \\
\hline \multirow{3}{*}{ Shaanxi } & GRP per capita (yuan) & 21,921 & 27,104 & 33,429 & 38,512 & 43,054 & 46,861 & 47,513 & 50,877 & 57,103 \\
\hline & $\begin{array}{l}\text { The density of } \\
\text { railways } \\
(\mathrm{km} / 1000 \mathrm{~km})\end{array}$ & 16.5 & 19.94 & 19.94 & 19.94 & 21.40 & 21.89 & 21.89 & 22.37 & 24.32 \\
\hline & $\begin{array}{l}\text { The density of } \\
\text { highways } \\
\left.(\mathrm{km} / 1000 \mathrm{~km})^{2}\right)\end{array}$ & 700.88 & 717.41 & 739.30 & 785.02 & 803.50 & 812.74 & 827.33 & 839.01 & 848.25 \\
\hline \multirow{3}{*}{ Gansu } & GRP per capita (yuan) & 13,259 & 16,097 & 19,580 & 21,917 & 24,519 & 26,387 & 26,117 & 27,588 & 28,408 \\
\hline & $\begin{array}{l}\text { The density of } \\
\text { railways } \\
\left.(\mathrm{km} / 1000 \mathrm{~km})^{2}\right)\end{array}$ & 5.64 & 5.64 & 5.64 & 5.87 & 6.11 & 7.98 & 8.92 & 9.63 & 11.04 \\
\hline & $\begin{array}{l}\text { The density of } \\
\text { highways } \\
\left.(\mathrm{km} / 1000 \mathrm{~km})^{2}\right)\end{array}$ & 267.73 & 279.24 & 290.51 & 308.13 & 313.76 & 324.33 & 329.03 & 335.84 & 334.19 \\
\hline \multirow{3}{*}{ Qinghai } & GRP per capita (yuan) & 19,412 & 23,986 & 29,409 & 33,046 & 36,714 & 39,508 & 41,106 & 43,381 & 43,893 \\
\hline & $\begin{array}{l}\text { The density of } \\
\text { railways } \\
\left(\mathrm{km} / 1000 \mathrm{~km}^{2}\right)\end{array}$ & 2.35 & 2.63 & 2.63 & 2.63 & 2.63 & 2.91 & 3.18 & 3.18 & 3.18 \\
\hline & $\begin{array}{l}\text { The density of } \\
\text { highways } \\
\left.(\mathrm{km} / 1000 \mathrm{~km})^{2}\right)\end{array}$ & 83.21 & 86.11 & 89.02 & 91.37 & 97.05 & 100.65 & 104.67 & 108.82 & 112 \\
\hline \multirow{3}{*}{ Ningxia } & GRP per capita (yuan) & 21,653 & 26,693 & 32,898 & 36,187 & 39,412 & 41,573 & 43,589 & 46,942 & 50,492 \\
\hline & $\begin{array}{l}\text { The density of } \\
\text { railways } \\
\left.(\mathrm{km} / 1000 \mathrm{~km})^{2}\right)\end{array}$ & 13.55 & 18.07 & 19.58 & 19.58 & 19.58 & 19.58 & 19.58 & 19.58 & 21.08 \\
\hline & $\begin{array}{l}\text { The density of } \\
\text { highways } \\
\left.(\mathrm{km} / 1000 \mathrm{~km})^{2}\right)\end{array}$ & 328.31 & 338.86 & 368.98 & 399.10 & 430.72 & 471.39 & 500 & 510.54 & 521.08 \\
\hline \multirow{3}{*}{ Xinjiang } & GRP per capita (yuan) & 19,810 & 24,474 & 29,923 & 33,611 & 37,296 & 40,354 & 39,512 & 40,241 & 44,507 \\
\hline & $\begin{array}{l}\text { The density of } \\
\text { railways } \\
\left(\mathrm{km} / 1000 \mathrm{~km}^{2}\right)\end{array}$ & 2.23 & 2.53 & 2.59 & 2.83 & 2.83 & 3.31 & 3.55 & 3.55 & 3.55 \\
\hline & $\begin{array}{l}\text { The density of } \\
\text { highways } \\
\left(\mathrm{km} / 1000 \mathrm{~km}^{2}\right)\end{array}$ & 90.78 & 92.05 & 93.49 & 99.94 & 102.53 & 105.72 & 107.41 & 109.7 & 111.63 \\
\hline
\end{tabular}

Source: Own calculation from primary data 
For comparison according to provinces, data regarding province- and year-specific GRP per capita, the density of railways, and the density of highways are converted into average values. For example, averages of GRP per capita according to provinces are values averaged over the year-specific data regarding GRP per capita, and the average of GRP per capita throughout provinces - the one averaged over the province-specific averages regarding GRP per capita.

Table 2. Province- and year- specific GRP per capita and densities of railways and highways (Coastal provinces)

\begin{tabular}{|c|c|c|c|c|c|c|c|c|c|c|}
\hline \multirow[t]{2}{*}{ Province } & \multirow[t]{2}{*}{ Indicator } & \multicolumn{9}{|c|}{ Year } \\
\hline & & 2009 & 2010 & 2011 & 2012 & 2013 & 2014 & 2015 & 2016 & 2017 \\
\hline \multirow{3}{*}{ Fujian } & $\begin{array}{c}\text { GRP per } \\
\text { capita (yuan) }\end{array}$ & 33,378 & 39,906 & 47,205 & 52,566 & 57,945 & 63,205 & 67,673 & 74,369 & 82,286 \\
\hline & $\begin{array}{c}\text { The } \\
\text { density of } \\
\text { railways } \\
\left(\mathrm{km} / 1000 \mathrm{~km}^{2}\right)\end{array}$ & 17.30 & 17.30 & 17.30 & 18.95 & 22.24 & 23.06 & 26.36 & 26.36 & 26.36 \\
\hline & $\begin{array}{c}\text { The } \\
\text { density of } \\
\text { highways } \\
\left(\mathrm{km} / 1000 \mathrm{~km}^{2}\right)\end{array}$ & 737.23 & 749.59 & 760.30 & 780.07 & 819.60 & 833.61 & 861.61 & 879.74 & 889.62 \\
\hline \multirow[t]{3}{*}{ Guangdong } & $\begin{array}{c}\text { GRP per } \\
\text { capita (yuan) }\end{array}$ & 38,976 & 44,070 & 50,652 & 53,868 & 58,695 & 63,232 & 67,115 & 73,511 & 80,316 \\
\hline & $\begin{array}{c}\text { The } \\
\text { density of } \\
\text { railways } \\
\left(\mathrm{km} / 1000 \mathrm{~km}^{2}\right)\end{array}$ & 13.89 & 15.00 & 15.56 & 15.56 & 19.44 & 22.22 & 22.22 & 23.33 & 23.33 \\
\hline & $\begin{array}{c}\text { The } \\
\text { density of } \\
\text { highways } \\
\left(\mathrm{km} / 1000 \mathrm{~km}^{2}\right)\end{array}$ & 1027.78 & 1056.11 & 1059.44 & 1082.78 & 1127.22 & 1178.33 & 1200 & 1211.67 & 1220 \\
\hline \multirow[t]{3}{*}{ Hainan } & $\begin{array}{c}\text { GRP per } \\
\text { capita (yuan) }\end{array}$ & 19,146 & 23,757 & 28,765 & 32,193 & 35,503 & 38,768 & 40,645 & 44,201 & 48,192 \\
\hline & $\begin{array}{c}\text { The } \\
\text { density of } \\
\text { railways } \\
\left(\mathrm{km} / 1000 \mathrm{~km}^{2}\right)\end{array}$ & 11.30 & 19.77 & 19.77 & 19.77 & 19.77 & 19.77 & 28.25 & 28.25 & 28.25 \\
\hline & $\begin{array}{c}\text { The } \\
\text { density of } \\
\text { highways } \\
\left(\mathrm{km} / 1000 \mathrm{~km}^{2}\right)\end{array}$ & 564.97 & 598.87 & 646.89 & 686.44 & 703.39 & 734.46 & 759.89 & 796.61 & 867.23 \\
\hline \multirow[t]{3}{*}{ Guangxi } & $\begin{array}{c}\text { GRP per } \\
\text { capita (yuan) }\end{array}$ & 15,979 & 20,759 & 25,233 & 27,841 & 30,621 & 32,968 & 35,036 & 37,862 & 37,919 \\
\hline & $\begin{array}{c}\text { The } \\
\text { density of } \\
\text { railways } \\
\left(\mathrm{km} / 1000 \mathrm{~km}^{2}\right)\end{array}$ & 13.05 & 13.47 & 13.47 & 13.47 & 16.84 & 19.78 & 21.46 & 21.89 & 21.89 \\
\hline & $\begin{array}{c}\text { The } \\
\text { density of } \\
\text { highways } \\
\left.(\mathrm{km} / 1000 \mathrm{~km})^{2}\right)\end{array}$ & 422.98 & 428.45 & 441.50 & 454.12 & 468.86 & 483.59 & 496.63 & 507.15 & 518.94 \\
\hline
\end{tabular}


(c) $L i$, An \& Rim

\begin{tabular}{|ccccccccccc|}
\hline Zhejiang & $\begin{array}{c}\text { GRP per } \\
\text { capita (yuan) }\end{array}$ & 43575.34 & 50894.64 & 59159.53 & 63292.55 & 68673.32 & 72935.78 & 77426.41 & 84528.37 & 91511.86 \\
\cline { 2 - 10 } & $\begin{array}{c}\text { The } \\
\text { density of } \\
\text { railways } \\
(\mathrm{km} / 1000 \mathrm{~km} \text { ) }\end{array}$ & 16.70 & 17.68 & 17.68 & 17.68 & 19.65 & 22.59 & 25.54 & 25.54 & 25.54 \\
\hline $\begin{array}{c}\text { The } \\
\text { density of } \\
\text { highways } \\
(\mathrm{km} / 1000 \mathrm{~km} \text { ) }\end{array}$ & 1051.08 & 1082.51 & 1098.23 & 1115.91 & 1133.60 & 1143.42 & 1159.14 & 1169.94 & 1179.76 \\
\hline
\end{tabular}

Source: Own calculation from primary data

Picturing the relationship between GRP per capita, the density of railways, and the density of highways, it is as follows (Figs 1 and 2). Figs 1 and 2 show the features of economic development and TI's development in the inland and coastal Chinese provinces directly affecting by BRI more clearly. From fig 1, it is seen that among inland provinces, while Shaanxi has the highest economic development level (GRP per capita $=40708$ yuan), Gansu - the lowest (GRP per capita $=22652$ yuan). For densities of railways and highways, Shaanxi is the highest (respectively, 20.86 and 785.94), and Qinghai - the lowest (respectively, 2.82 and 96.99). However, for GRP per capita, Qinghai is the third (34 495 yuan). Ningxia is the second for three indicators (respectively, 37 715, 18.91, and 429.89). Thus, it seems to be a close relation between three indicators in Shaanxi and Ningxia, but it is ambiguous in others. For coastal provinces, too, it can be explained similarly.

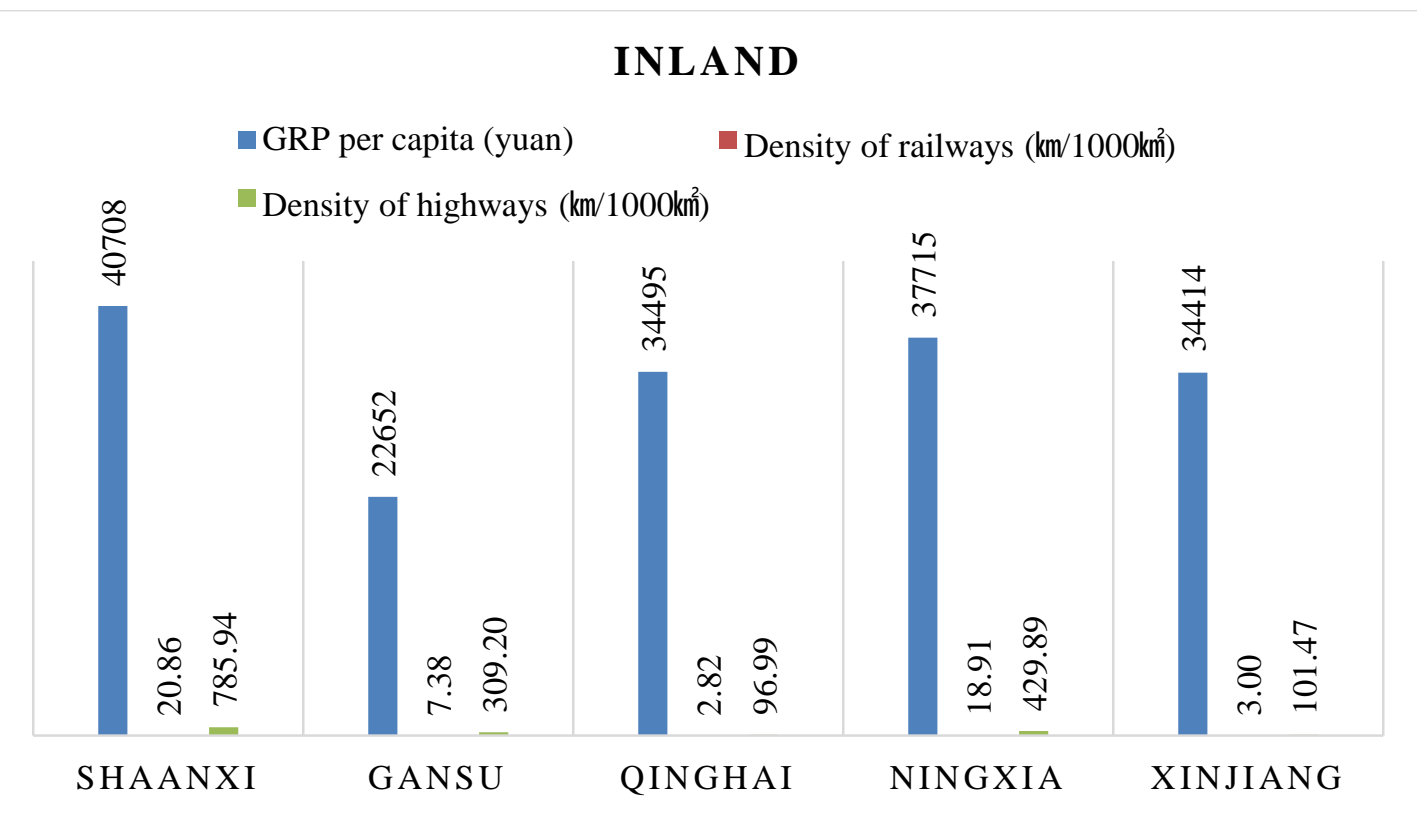

Fig 1. Relationship between GRP per capita and densities of railways and highways (Inland province)

Source: Own elaboration

From fig 2, it is seen that among coastal provinces, Zhejiang has not only the highest economic development level (GRP per capita $=68000$ yuan) but also high densities of railways and highways (respectively, 20.96 and 1125.95). Fujian can be explained similarly to the abovementioned. However, Guangxi is the lowest for three indicators (respectively, 29 357, 
17.26, and 469.14). Thus, it seems to be a close relation between three indicators for almost all provinces.

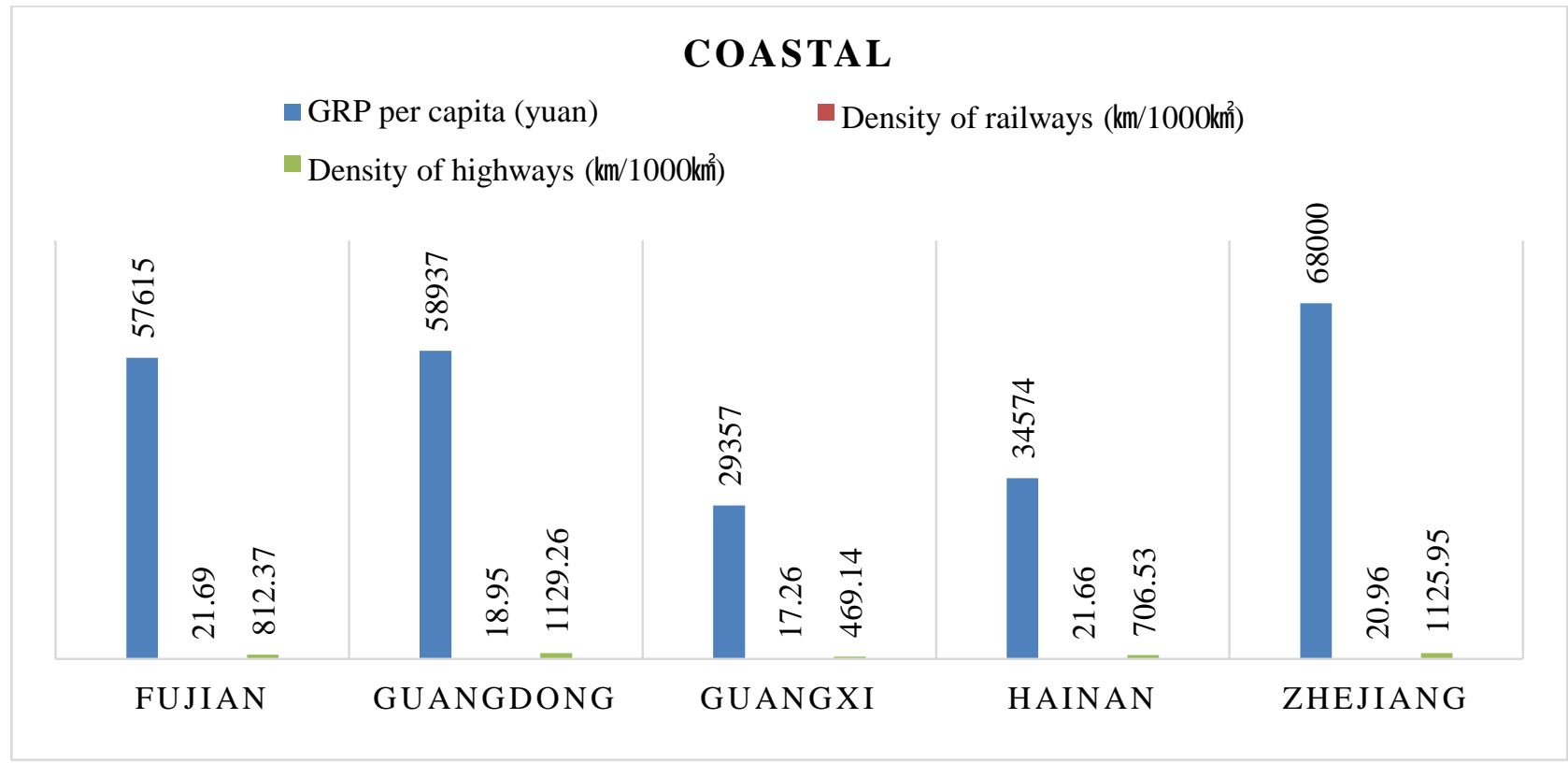

Fig 2. Relationship between GRP per capita, densities of railways and highways (Coastal provinces)

Source: Own elaboration

Comparing the whole of inland provinces with those of coastal provinces, it is as follows (Fig 3).

Density of highways $\left(\mathrm{km} / 1000 \mathrm{~km}^{2}\right) \quad \square$ Density of railways $\left(\mathrm{km} / 1000 \mathrm{~km}^{2}\right) \quad$ GRP per capita (yuan)

Coastal Provinces

848.65

20.10

49696.75

Inland Provinces

344.70

10.59

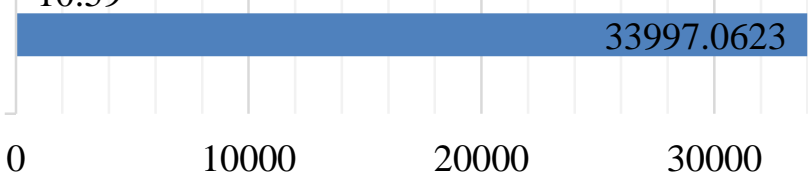

40000

50000

60000

Fig 3. Comparison between inland and coastal provinces according to averages of three indicators.

Source: Own elaboration

Fig 3 shows that coastal provinces have higher levels than inland provinces for three indicators. As seen from the above tables and figures, it shows that GRP and TI's elements grow, the growth of highways is faster than that of railways, and in turn, the growth of GRP is faster than that of highways in provinces directly affecting BRI over the period under study. Furthermore, 
it is seen that growths of three indicators differ between inland and coastal provinces, among inland provinces, and coastal provinces. This makes it possible to analyze the impact of TI on GRP in provinces under study. Thus, the next section discusses the method to examine and analyze the relation between three indicators.

\subsection{Methods}

To analyze the impacts of railways and highways on GRP in provinces under study, authors conduct the correlation and regression analysis and use the statistical package SPSS. Conducting the correlation and regression analysis is based on assumption that GRP and diverse TI's elements are in close relation and these elements affect the GRP diversely. Also, the degree of changes in GRP according to changes in TI's elements can easily be estimated by drawing regression models. SPSS makes it possible to conduct regression analysis by treating large panel data conveniently. For regression analysis, authors construct the correlation matrix and regression models, and in turn, conduct the statistical forecasts. GRP per capita is selected as the dependent variable, and densities of railways and highways - independent variables for provinces under study.

\subsubsection{Calculation of correlation coefficients}

First of all, the authors calculate the correlation coefficients regarding each province and whole inland and coastal provinces under study. Correlation coefficients make it possible to reveal the impacts of densities of railways and highways on GRP per capita and the correlation between densities of railways and highways.

Correlation coefficients regarding inland provinces are as follows (see table 3).

Table 3. Correlation coefficients a (Inland provinces)

\begin{tabular}{|c|c|c|c|c|}
\hline Province ${ }^{b}$ & Independent & $\begin{array}{c}\text { The density of } \\
\text { railways }(\mathrm{km} / 1000 \\
\left.\mathrm{km}^{2}\right)\end{array}$ & $\begin{array}{c}\text { The density of } \\
\text { highways }(\mathrm{km} / 1000 \\
\left.\mathrm{km}^{2}\right)\end{array}$ & $\begin{array}{c}\text { Correlation } \\
\text { between } \\
\text { independent } \\
\text { variables } \\
\end{array}$ \\
\hline Shaanxi & $\begin{array}{c}\text { GRP per capita } \\
\text { (yuan) }\end{array}$ & $.937^{* *}$ & $.986^{* *}$ & $.893^{* *}$ \\
\hline Gansu & $\begin{array}{l}\text { GRP per capita } \\
\text { (yuan) }\end{array}$ & $.811^{* *}$ & $.992^{* *}$ & $.836^{* *}$ \\
\hline Qinghai & $\begin{array}{l}\text { GRP per capita } \\
\text { (yuan) }\end{array}$ & $.898^{* *}$ & $.961^{* *}$ & $.943^{* * *}$ \\
\hline Ningxia & $\begin{array}{l}\text { GRP per capita } \\
\text { (yuan) }\end{array}$ & $.823^{* *}$ & $.972^{* *}$ & $.691^{*}$ \\
\hline Xinjiang & $\begin{array}{l}\text { GRP per capita } \\
\text { (yuan) }\end{array}$ & $.929^{* *}$ & $.961^{* *}$ & $.966^{* *}$ \\
\hline Whole $^{c}$ & $\begin{array}{l}\text { GRP per capita } \\
\text { (yuan) }\end{array}$ & $.436^{* *}$ & $.364^{*}$ & $.915^{* *}$ \\
\hline
\end{tabular}

Note: ${ }^{* *}$. Correlation is significant at the 0.01 level (2-tailed).

*. Correlation is significant at the 0.05 level (2-tailed).

a Pearson Correlation, ${ }^{b}$ number of observations $=9,{ }^{c}$ number of observations $=45$

Source: Own calculation 
Correlation coefficients show the features in impacts of TI's elements on GRP according to inland provinces. In other words, in general, railways and highways have strong correlations with GRP in all inland provinces, but their degrees differ. Shaanxi has the strongest correlation of railways with GRP (0.937), Gansu - the strongest correlation of highways (0.992), and Xinjiang has the strongest correlation between two independent variables (0.966). Correlation coefficients are statistically significant at the one or five percent.

Correlation coefficients regarding coastal provinces are presented in table 4. Cases for coastal provinces are similar to inland provinces, too. Generally, railways and highways have strong correlations with GRP in all coastal provinces, but their degrees differ. Guangdong has the strongest correlation of railways with GRP (0.944), Hainan - the strongest correlation of highways (0.992), On the other hand, Guangdong has the strongest correlation between railways and highways $(0.991)$. Correlation coefficients are statistically significant at the one or five percent.

Table 4. Correlation coefficients a (Coastal provinces)

\begin{tabular}{|ccccc|}
\hline Province ${ }^{\mathrm{b}}$ & Independent & $\begin{array}{c}\text { The density } \\
\text { of railways }(\mathrm{km} \\
/ 1000 \mathrm{~km})\end{array}$ & $\begin{array}{c}\text { The } \\
\text { density of } \\
\text { highways }(\mathrm{km} \\
/ 1000 \mathrm{~km})\end{array}$ & $\begin{array}{c}\text { Correlation } \\
\text { between } \\
\text { independent } \\
\text { variables }\end{array}$ \\
\hline Fujian & $\begin{array}{c}\text { GRP per capita } \\
\text { (yuan) }\end{array}$ & $.941^{* *}$ & $.982^{* *}$ & $.986^{* *}$ \\
\hline Guangdong & $\begin{array}{c}\text { GRP per capita } \\
\text { (yuan) }\end{array}$ & $.944^{* *}$ & $.965^{* *}$ & $.991^{* *}$ \\
\hline Guangxi & $\begin{array}{c}\text { GRP per capita } \\
\text { (yuan) }\end{array}$ & $.910^{* *}$ & $.973^{* *}$ & $.961^{* *}$ \\
\hline Hainan & $\begin{array}{c}\text { GRP per capita } \\
\text { (yuan) }\end{array}$ & $.880^{* *}$ & $.992^{* *}$ & $.974^{* *}$ \\
\hline Zhejiang & $\begin{array}{c}\text { GRP per capita } \\
\text { (yuan) }\end{array}$ & $.920^{* *}$ & $.989^{* *}$ & $319^{*}$ \\
\hline Whole c & $\begin{array}{c}\text { GRP per capita } \\
\text { (yuan) }\end{array}$ & $.620^{* *}$ & $.816^{* *}$ & \\
\hline
\end{tabular}

Note: ${ }^{* *}$. Correlation is significant at the 0.01 level (2-tailed).

*. Correlation is significant at the 0.05 level (2-tailed).

${ }^{\mathrm{a}}$ Pearson Correlation, ${ }^{\mathrm{b}}$ number of observations $=9,{ }^{\mathrm{c}}$ number of observations $=27$.

Source: Own calculation

Correlation coefficients are of significance in not only revealing the relationship between GRP per capita and densities of railways and highways but also examining the multicollinearity of regression equations.

\subsubsection{Construction and analysis of regression models}

Given those correlations of railways and highways with GRP are calculated, linear regression models are constructed and analyzed in provinces under study. Construction and analysis of regression models are conducted according to each province and regarding whole inland and coastal provinces. Results of construction and analysis are presented in Appendices A and B. 
Under regression analysis, significance and availability of regression models were tested, and thus, based on them, impacts of railways and highways on GRP according to inland and coastal provinces under study are analyzed, and province-specific GRPs per capita are estimated.

Regression equations according to provinces can be described as follows.

$$
\begin{aligned}
& \text { Inland provinces } \\
& \text { Shaanxi: } y=-111120.491+1397.663 x_{1}+156.086 x_{2} \\
& \text { Gansu: } y=-45407.050-156.439 x_{1}+223.855 x_{2} \\
& \text { Qinghai: } y=-44537.692-1909.814 x_{1}+870.261 x_{2} \\
& \text { Ningxia: } y=-27932.846+1269.433 x_{1}+96.874 x_{2} \\
& \text { Xinjiang: } y=-67178.397+52.947 x_{1}+999.623 x_{2} \\
& \text { Whole inland: } y=28242.593+821.526 x_{1}-8.552 x_{2}
\end{aligned}
$$

\section{Coastal provinces}

Fujian: $\quad y=-305287.744-4077.242 x_{1}+555.59 x_{2}$;

Guangdong: $y=-233011.691-2397.334 x_{1}+298.761 x_{2}$;

Guangxi: $y=-93116.614-647.107 x_{1}+284.868 x_{2}$;

Hainan: $y=-33933.821+92.498 x_{1}+94.130 x_{2}$;

Zhejiang: $y=-312153.435+334.860 x_{1}+331.395 x_{2}$;

Whole coastal: $y=1735.011+1735.011 x_{1}+50.979 x_{2}$;

where $x_{1}$ - the density of railways $(\mathrm{km} / 1000 \mathrm{~km})$

$x_{2}$ - the density of highways $\left(\mathrm{km} / 1000 \mathrm{~km}{ }^{2}\right)$

$y$ - GRP per capita (yuan)

Constructing the regression models, significance provability, contribution degree, and standard error of estimate are calculated, and they are meaningful results. For example, for the whole of inland provinces, significance provability is $0.00(<\mathrm{p}$-value $=0.05)$, contribution degree $\left(\mathrm{R}^{2}\right)-$ 0.197, and standard error of estimate - 9606.013. This shows that the regression equation is significant and statistically meaningful, $x_{1}$ and $x_{2}$ explain $19.7 \%$ of changes in GRP per capita, and the error interval of GRP per capita is in \pm 9606.013 (yuan). However, in each province, contribution degrees of independent variables to a dependent variable are all higher than the case for the whole of inland provinces. On the other hand, for the whole of coastal provinces, significance provability is 0.00 ( $\mathrm{p}$-value $<\alpha=0.05$ ), contribution degree $\left(\mathrm{R}^{2}\right)-0.810$, and standard error of estimate - 8702.173. This shows that the regression equation is significant and statistically meaningful, $x_{1}$ and $x_{2}$ explain $81 \%$ of changes in GRP per capita, and the error interval of GRP per capita is in \pm 8702.17338 (yuan).

As seen from regression equations for some provinces, it is seen that some regression coefficients have a negative sign (minus). For example, those are the cases for Gansu, Qinghai, Fujian, Guangdong, and Guangxi. This does not mean that corresponding coefficients are not statistically significant. To test the significance of regression coefficients, analysis of variance is conducted, and its results are presented in tables A2 and B2. From tables A2, A3, B2, and B3, it is confirmed that the abovementioned coefficients are all significant, because it is said that if the $\mathrm{t}$-value is smaller than 0.05 or F-value is above two, corresponding regression coefficient is 
significant empirically. In this case, it can say that corresponding coefficients have fewer impacts on GRP per capita compared to those with a positive sign (plus).

To reveal the explanatory abilities of independent variables in estimating the dependent ones, it is necessary to examine the multicollinearity of regression equations. Empirically, it is said that if $\mathrm{R}^{2}>$ correlation coefficient between independent variables, there is no multicollinearity and vice versa. From tables 3, 4, A1, and B1, it is seen that regression equations for Qinghai, Xinjiang, and Guangxi have the multicollinearities. To relax the impacts of multicollinearity, it is reasonable to eliminate the independent variable or introduce a new control variable. However, to do this is impossible, because these equations include only two variables as independent, it is impossible to find common control variables affecting GRP per capita and densities of two indicators, and construction of regressions equations is aimed to estimating GRP per capita. Thus, it can say that if differences between predicted results and actual values are in a certain range, the corresponding equation is efficient in estimating the results. Empirically, it is said that if the standard residual is not beyond 2.5, then the corresponding regression equation is efficient. As seen from tables A4 and B4, standard residuals are not beyond 2.5, and thus, it is concluded that regression equations for all provinces are meaningful and efficient.

\section{Results}

Authors constructed the correlation matrix and conducted the regression analysis to analyze the impacts of railways and highways and to estimate GRP per capita in the Chinese provinces directly affecting by BRI

First, the authors conducted a correlation analysis regarding individual or whole inland and coastal provinces. As a result, for inland provinces, highways has a stronger correlation with GRP than railways, and for coastal provinces, highways have stronger correlations than railways. Next, the authors conducted a regression analysis to analyze the impacts of railways and highways on GRP per capita in individual provinces and to obtain regression models for estimating GRP per capita. As a result, it is seen that contributions of railways and highways to GRP per capita are higher in coastal than inland and in contrast, standard error of the estimate is higher in the inland than coastal. Next, the authors tested the significance of regression equations and coefficients. Interpretations on correlations of railways and highways with GRP per capita and on results of regression analysis in provinces under study were discussed in Section 3. As a result, it is found that regression coefficients and equations for all provinces are significant and efficient in estimating the GRP per capita.

\section{Conclusion}

This study aims to analyze and forecast the impacts of railways and highways on GRP per capita in the inland and coastal Chinese provinces directly affecting by BRI, and to help in rational decision-making related to investment in railways and highways under execution of BRI. Therefore, the authors conducted the correlation and regression analysis using data regarding the development level of railways and highways from 2009 to 2017 according to ten provinces directly affecting by BRI. From findings discussed in Section 4, it is concluded as 
follows; the first conclusion is that railways and highways contribute to GRP per capita positively under BRI, and these contributions have differed among individual inland and coastal provinces, and between wholes of inland and coastal provinces; the second conclusion is that railways and highways affect GRP per capita differently according to correlations between them. This study can contribute to making decisions related to investment in railways and highways for ensuring purposeful GDP per capita under the future execution of BRI. Of course, our study has some limitations. First, we conducted the analysis using data regarding some elements of TI, that is, railways and highways due to the limit of data. This makes to be difficult to ensure the reliability and correctness of the analysis. Thus, to ensure the correctness of the result, it is rational to use many data as possible. Second, we did not ensure the correctness in analysis enough due to selecting an analysis period of 9 years. The correctness of the result depends on catching long-term data. Therefore, there exists a serious deviation between analysis results using long- and short-term data. Finally, other factors in addition to TI's elements are not considered. Therefore, it is necessary to select data regarding all elements of infrastructure, take a long-term analysis period as possible, and consider other factors affecting GRP per capita in addition to infrastructural elements. In particular, it is desirable to analyze the impacts of TI's elements on GRP per capita, dividing the analysis period into pre- and post-BRI periods. It is our view that to do so can enhance the correctness and reliability of analysis and help in practical decision-making related to infrastructural investment under BRI.

Acknowledgment: The authors like to thank the chief of the Center for North and South Korea Studies, Professor Cankui Piao at Yanbian University, China for insightful comments and materials related to "Belt, and Road" Initiative.

Authors' Contributions: Jin-Hui Li conceived the idea and collected data; Chol-Ju An wrote the paper; Gwang-Nam Rim analyzed the data.

Conflict of interest: The authors declare no conflict of interest.

\section{REFERENCES}

Aschauer, D. (1989). Is public expenditure productive? Journal of Monetary Economics, 23, pp. 177-200.

Bajo-Rubio, O. \& Sosvilla-Riviero, S. (1993). Does public capital affect private sector performance? An analysis of the Spanish case 1964-88, Economic Modelling, 10(3), pp. 179-185.

Berndt, E. \& Hansson, B. (1992). Measuring the contribution of public infrastructure capital in Sweden, The Scandinavian Journal of Economics, 94, pp. 151-168.

Binswanger H. P., Khandker, S. R. \& Rosenzweig, M. R. (1992). How Infrastructure and Financial Institutions Affect Agricultural Output and Investment in India, Journal of Development Economics, 41, 337-366.

Buys, P., Deichmann, U. \& Wheeler, D. (2006). Road Network Upgrading and Overland Trade Expansion in SubSaharan Africa, World Bank Policy Research Working Paper No. 4097.

Chakraborty, C. \& B. Nandi (2011). 'Mainline' telecommunications infrastructure, levels of development and economic growth: Evidence from a panel of developing countries, Telecommunications Policy, 35, pp. 441449.

Costa, J., Ellson, R. \& Martin, R. (1987). Public capital, regional output, and development: some empirical evidence, Journal of Regional Science, 27(3), pp. 419-437. 
Demetriades, P. \& Mamuneas, T. (2000). Intertemporal output and employment effects of public infrastructure capital: evidence from 12 OECD economies, Economic Journal, 110, pp. 687-712.

Dethier, J. J., Hirn, M. \& Straub, S. (2008). Explaining Enterprise Performance in Developing Countries with Business Climate Survey Data, Policy Research Working Paper, 4792, Washington, DC, World Bank.

Estache, A., Speciale, B. \& Veredas, D. (2005). How much does infrastructure matter to growth in Sub-Saharan Africa, European Center for Advanced Research in Economics, Working Paper, Universite Libre de Bruxelles.

Estache, A. \& Fay, M. (2010). Current Debates on Infrastructure Policy, in Globalization and Growth: Implications for a Post-Crisis World, Commission on Growth and Development, Edited by Michael Spence and Danny Leipziger, pp. 151-193

Fernald, J. (1993). How productive is infrastructure? Distinguishing reality and illusion with a panel of U.S. industries, Board of Governors of the Federal Reserve System, August.

Fernald, J. (1999). Assessing the link between public capital and productivity, American Economic Review, 89(3), pp. 619-638.

Garsous, G. (2012). How Productive is Infrastructure? A Quantitative Survey, ECARES Working Paper, Université libre de Bruxelles.

Greenstein, S. \& Spiller, P. (1995). Modern telecommunications infrastructure and economic activity: an empirical investigation, Industrial and Corporate Change, 4(4), pp. 647-665.

Haggai, K. (2016). One Belt One Road Strategy in China and Economic Development in the Concerning Countries. World Journal of Social Sciences and Humanities, 2(1), pp. 10-14. Available at: DOI: 10.12691/wjssh-2-1-2.

Li, J. H., Rim, G. N. \& An, C. J. (2020). Relationship between Transport Infrastructure and Employment: Evidence from the Chinese Inland Provinces under the "One Belt, One Road" Initiative. Business Perspective Review, 2(1), 13-28. Available at: DOI: https://doi.org/10.38157/business-perspective-review.v2i1.103.

Ligthart, J. (2002). Public capital and output growth in Portugal: an empirical analysis, European Review of Economics and Finance, 1(2), pp. 3-30.

Mamatzakis, E. (1999). Testing for long run relationship between infrastructure and private capital productivity: a time series analysis for the Greek industry, Applied Economics Letters, 6 (4), pp. 243-246.

Nadiri, M. \& Mamuneas, T. (1994). The effects of public infrastructure and R\&D capital on the cost structure and performance of U.S. manufacturing industries, The Review of Economics and Statistics, 76(1), pp. 22-37.

Nadiri, M. \& Mamuneas, T. (1996). Contribution of highway capital to industry and national productivity growth, Report prepared for Apogee Research, Inc., for the Federal Highway Administration Office of Policy Development.

National Bureau of Statistics of China, (2019). National data. Accessed: 2019-09-18, Available at: http://www.stats.gov.cn/english/easyquery.htm?cn=E0103

National Development and Reform Commission, Ministry of Foreign Affairs, and Ministry of Commerce of the People's Republic of China, (2015a). Visions and Proposed Actions on Jointly Building Silk Road Economic Belt and 21st-Century Maritime Silk Road. Available at http://en.ndrc.gov.cn/newsrelease/201503/t20150330 669367.html

National Development and Reform Commission, Ministry of Foreign Affairs, and Ministry of Commerce of the People's Republic of China, (2015b). Visions and Proposed Actions on Jointly Building Silk Road Economic Belt and 21st-Century Maritime Silk Road. Available at: http://en.ndrc.gov.cn/newsrelease/201503/t20150330_669367.html

$\mathrm{Ni}, \mathrm{A},(2013)$. The Analysis of the Impact of Transportation Infrastructure Investment on the China's Economic Growth, Economic Research Guide, Serial No.194.

Otto, G. \& Voss, G. (1994). Public capital and private sector productivity, The Economic Record, 70(209), pp. 121-132.

Otto, G. \& Voss, G. (1996). Public capital and private production in Australia, Southern Economic Journal, 62(3), pp. 723-738.

Pereira, A. \& Roca-Sagales, O. (1999). Public capital formation and regional development in Spain, Review of Development Economics, 3(3), pp. 281-294. 
Pereira, A. \& Andraz, J. (2003). On the impact of public investment on the performance of US industries, Public Finance Review, 31(1), pp. 66-90.

Pereira, A. \& Andraz, J. (2013). On the economic effects of public infrastructure investment: A survey of the international evidence, Journal of Economic Development, Chung-Ang University, Department of Economics, 38(4), pp. 1-37.

Peter, C. (2017a). Understanding China's Belt and Road Initiative, Lowy Institute. March 22.2017. Available at: https://www.lowyinstitute.org/publications/understanding-belt-and-road-initiative.

Peter, C. (2017b). Understanding China's Belt and Road Initiative, Lowy Institute. March 22.2017. Available at: https://www.lowyinstitute.org/publications/understanding-belt-and-road-initiative.

Pinnoi, N. (1992). Public capital and stock productivity growth: further evidence from error components model, Empirical Economics, 20(2), pp. 351-59.

The Economist, (2016). "Regional Development: Rich Province, Poor Province", 1 October 2016. Available at: http://www.economist.com/news/china/21707964-government-struggling-spread-wealth-more-evenlyrich-province-poor-province.

Yifei, C. (2016). Three Strategies Shoulder the Common Destiny, The People's Daily (overseas edition), 20 September 2016, Available at http://paper.people.com.cn/rmrbhwb/html/2016-09/20/content_1713601.htm.

Yingying, S., Shen, G. \& Puyang, S. (2017). The role of infrastructure in China's regional economic growth, Journal of Asian Economics, 49, pp. 26-41.

Ylander, A. (2017a). The impact of 'One Belt, One Road' and its Effects on GDP growth in China. Available at: https://gupea.ub.gu.se/handle/2077/52800

Ylander, A. (2017b). The impact of 'One Belt, One Road' and its Effects on GDP growth in China. Available at: https://gupea.ub.gu.se/handle/2077/52800.

Youqing, G. (2015). One Belt and One Road: The Fourth Wave of Investment, in Leading Scholars from National Think Tanks and Their Insights on China's New Silk Road, Beijing: CITIC Press.

Wang Xiaolu, W., Yu Wenjing, Y., and Fan Gang, F. (2016). A Progress Report on Eight Years of China's March Towards the Free Market Economy, Caijing Magazine, 11 April.

Wilson, J. S., Mann, C. L. \& Tsunehiro, O. (2003). Trade facilitation and economic development: measuring the impact, Policy Research Working Paper Series 2988, The World Bank.

Xinmin, C., Jinquan L. \& Yi, F. (2017). A Study on the Impact of China's Transportation Infrastructure Construction on Economic Growth. Available at: DOI: 10. 16528 /j. cnki. 22 - 1054 /f. 201704068.

Zhan-Wei, Qiang, C. \& Pitt, A. (2004). Contribution of Information and Communication Technologies to Growth, World Bank Publications No. 24.

(C) 2020 by the authors. Licensee Research $\mathcal{E}$ Innovation Initiative, Michigan, USA. This article is an open-access article distributed under the terms and conditions of the Creative Commons Attribution (CC BY) license (http://creativecommons.org/licenses/by/4.0/). 


\section{Appendix A and B}

\section{Appendix A. Results of regression analysis}

(Inland provinces)

Table A1. Contribution of independent variables to the dependent variable ${ }^{b}$

\begin{tabular}{|c|c|c|c|c|}
\hline Model & $\mathbf{R}$ & $\mathbf{R}^{\mathbf{2}}$ & ${\text { Adjusted } \mathbf{R}^{\mathbf{2}}}^{\text {The standard error }}$ & $\begin{array}{c}\text { Ther } \\
\text { of estimate }\end{array}$ \\
\hline Shaanxi & $.994^{\mathrm{a}}$ & .988 & .984 & 1447.683 \\
\hline Gansu & $.992^{\mathrm{a}}$ & .984 & .979 & 769.040 \\
\hline Qinghai & $.961^{\mathrm{a}}$ & .923 & .898 & 2786.353 \\
\hline Ningxia & $.961^{\mathrm{a}}$ & .923 & .898 & 2786.353 \\
\hline Xinjiang & $.961^{\mathrm{a}}$ & .924 & .899 & 2612.486 \\
\hline Whole & $.444^{\mathrm{a}}$ & .197 & .159 & 9606.013 \\
\hline
\end{tabular}

Note: a. Predictors: (Constant), the density of railways $\left(\mathrm{km} / 1000 \mathrm{~km}^{2}\right)$, the density of highways $\left(\mathrm{km} / 1000 \mathrm{~km}^{2}\right)$

b. Dependent variable: GRP per capita (yuan)

Table A2. Analysis of Variance (ANOVA) ${ }^{b}$

\begin{tabular}{|c|c|c|c|c|c|c|}
\hline \multicolumn{2}{|c|}{ Model a $^{\text {a }}$} & Sum of & Degree of & Mean Square & $\mathbf{F}$ & Significance \\
\hline Shaanxi & $\begin{array}{c}\text { Regression } \\
\text { Residual } \\
\text { Total } \\
\end{array}$ & $\begin{array}{l}1.045 \mathrm{E} 9 \\
1.257 \mathrm{E} 7 \\
1.058 \mathrm{E} 9 \\
\end{array}$ & $\begin{array}{l}2 \\
6 \\
8 \\
\end{array}$ & $\begin{array}{c}5.226 \mathrm{E} 8 \\
2095787.095\end{array}$ & 249.379 & $.000^{\mathrm{a}}$ \\
\hline Gansu & $\begin{array}{c}\text { Regression } \\
\text { Residual } \\
\text { Total } \\
\end{array}$ & $\begin{array}{c}2.246 \mathrm{E} 8 \\
3548537.424 \\
2.281 \mathrm{E} 8 \\
\end{array}$ & $\begin{array}{l}2 \\
6 \\
8 \\
\end{array}$ & $\begin{array}{c}1.123 \mathrm{E} 8 \\
591422.904\end{array}$ & 189.850 & $.000^{\mathrm{a}}$ \\
\hline Qinghai & $\begin{array}{c}\text { Regression } \\
\text { Residual } \\
\text { Total } \\
\end{array}$ & $\begin{array}{l}5.604 \mathrm{E} 8 \\
4.658 \mathrm{E} 7 \\
6.069 \mathrm{E} 8\end{array}$ & $\begin{array}{l}2 \\
6 \\
8 \\
\end{array}$ & $\begin{array}{c}2.802 \mathrm{E} 8 \\
7763763.040\end{array}$ & 36.088 & $.000^{\mathrm{a}}$ \\
\hline Ningxia & $\begin{array}{c}\text { Regression } \\
\text { Residual } \\
\text { Total } \\
\end{array}$ & $\begin{array}{c}6.971 \mathrm{E} 8 \\
8521736.742 \\
7.057 \mathrm{E} 8 \\
\end{array}$ & $\begin{array}{l}2 \\
6 \\
8 \\
\end{array}$ & $\begin{array}{c}3.486 \mathrm{E} 8 \\
1420289.457\end{array}$ & 245.424 & $.000^{\mathrm{a}}$ \\
\hline Xinjiang & $\begin{array}{c}\text { Regression } \\
\text { Residual } \\
\text { Total } \\
\end{array}$ & $\begin{array}{l}4.973 \mathrm{E} 8 \\
4.095 \mathrm{E} 7 \\
5.383 \mathrm{E} 8 \\
\end{array}$ & $\begin{array}{l}2 \\
6 \\
8 \\
\end{array}$ & $\begin{array}{c}2.487 \mathrm{E} 8 \\
6825080.699\end{array}$ & 36.435 & $.000^{\mathrm{a}}$ \\
\hline Whole & $\begin{array}{c}\text { Regression } \\
\text { Residual } \\
\text { Total } \\
\end{array}$ & $\begin{array}{l}9.530 \mathrm{E} 8 \\
3.876 \mathrm{E} 9 \\
4.829 \mathrm{E} 9\end{array}$ & $\begin{array}{c}2 \\
42 \\
44 \\
\end{array}$ & $\begin{array}{l}4.765 \mathrm{E} 8 \\
9.228 \mathrm{E} 7\end{array}$ & 5.164 & $.000^{\mathrm{a}}$ \\
\hline
\end{tabular}

Note: a. Predictors: (Constant), the density of railways $\left(\mathrm{km} / 1000 \mathrm{~km}^{2}\right)$, the density of highways $\left(\mathrm{km} / 1000 \mathrm{~km}^{2}\right)$

b. Dependent variable: GRP per capita (yuan)

Source: Compiled by authors 
(C) $L i$, An \& Rim

Table A3. Regression coefficients ${ }^{a}$

\begin{tabular}{|c|c|c|c|c|c|c|c|c|}
\hline \multirow{2}{*}{\multicolumn{2}{|c|}{ Model }} & \multicolumn{2}{|c|}{$\begin{array}{c}\text { Unstandardized } \\
\text { Coefficients }\end{array}$} & \multirow{2}{*}{$\begin{array}{c}\text { Standardized } \\
\text { Coefficients } \\
\text { Beta }\end{array}$} & \multirow[t]{2}{*}{$\mathbf{t}$} & \multirow[t]{2}{*}{ Significance } & \multicolumn{2}{|c|}{$\begin{array}{l}95 \% \text { Confidence } \\
\text { Interval for B }\end{array}$} \\
\hline & & $\mathrm{B}$ & $\begin{array}{l}\text { Standard } \\
\text { Error }\end{array}$ & & & & $\begin{array}{l}\text { Lower } \\
\text { Bound }\end{array}$ & $\begin{array}{l}\text { Upper } \\
\text { Bound }\end{array}$ \\
\hline \multirow[t]{3}{*}{ Shaanxi } & (Constant) & $\begin{array}{c}- \\
111120.49 \\
1 \\
\end{array}$ & 8631.059 & & -12.874 & .000 & -132239.932 & -90001.050 \\
\hline & $\begin{array}{l}\text { The density } \\
\text { of highways } \\
\left(\mathrm{km} / 1000 \mathrm{~km}^{2}\right)\end{array}$ & 1397.66 & 493.787 & .280 & 2.830 & .030 & 189.409 & 2605.917 \\
\hline & $\begin{array}{l}\text { The density } \\
\text { of railways } \\
\left(\mathrm{km} / 1000 \mathrm{~km}^{2}\right)\end{array}$ & 156.086 & 20.939 & .736 & 7.454 & .000 & 104.850 & 207.322 \\
\hline \multirow[t]{3}{*}{ Gansu } & (Constant) & -45407.050 & 4789.377 & & -9.481 & .000 & -57126.234 & -33687.865 \\
\hline & $\begin{array}{l}\text { The density } \\
\text { of highways } \\
\left(\mathrm{km} / 1000 \mathrm{~km}^{2}\right)\end{array}$ & -156.439 & 239.824 & -.061 & -.652 & .538 & -743.268 & 430.390 \\
\hline & $\begin{array}{l}\text { The density } \\
\text { of railways } \\
\left(\mathrm{km} / 1000 \mathrm{~km}^{2}\right)\end{array}$ & 223.855 & 19.934 & 1.042 & 11.230 & .000 & 175.077 & 272.633 \\
\hline \multirow[t]{3}{*}{ Qinghai } & (Constant) & -44537.692 & 9382.906 & & -4.747 & .003 & -67496.836 & -21578.548 \\
\hline & $\begin{array}{l}\text { The density } \\
\text { of highways } \\
\left(\mathrm{km} / 1000 \mathrm{~km}^{2}\right)\end{array}$ & $\begin{array}{c}- \\
- \\
1909.814\end{array}$ & .729 & -.071 & -.239 & .819 & -25400.338 & 21580.710 \\
\hline & $\begin{array}{l}\text { The density } \\
\text { of railways } \\
\left(\mathrm{km} / 1000 \mathrm{~km}^{2}\right)\end{array}$ & 870.261 & .022 & 1.037 & 3.471 & .013 & 163.267 & 1577.255 \\
\hline \multirow[t]{3}{*}{ Ningxia } & (Constant) & -27932.846 & 3739.257 & & -7.470 & .000 & -37082.478 & -18783.214 \\
\hline & $\begin{array}{l}\text { The density } \\
\text { of highways } \\
\left(\mathrm{km} / 1000 \mathrm{~km}^{2}\right)\end{array}$ & 1269.43 & 271.593 & .290 & 4.674 & .003 & 604.869 & 1933.997 \\
\hline & $\begin{array}{l}\text { The density } \\
\text { of railways } \\
\left(\mathrm{km} / 1000 \mathrm{~km}^{2}\right)\end{array}$ & 96.874 & 7.795 & .771 & 12.428 & .000 & 77.800 & 115.947 \\
\hline \multirow[t]{2}{*}{ Xinjiang } & (Constant) & -67178.397 & 26295.851 & & -2.555 & .043 & -131522.025 & -2834.768 \\
\hline & $\begin{array}{l}\text { The density } \\
\text { of highways } \\
\left(\mathrm{km} / 1000 \mathrm{~km}^{2}\right)\end{array}$ & 52.947 & 7085.861 & .003 & .007 & .994 & -17285.531 & 17391.425 \\
\hline
\end{tabular}


Business Perspective Review 2(2), 2020

\begin{tabular}{|c|c|c|c|c|c|c|c|c|}
\hline & $\begin{array}{l}\text { The density } \\
\text { of railways } \\
\left(\mathrm{km} / 1000 \mathrm{~km}^{2}\right)\end{array}$ & 999.623 & 455.493 & .958 & 2.195 & .071 & -114.928 & 2114.174 \\
\hline \multirow[t]{3}{*}{ Whole } & (Constant) & 28242.593 & 2422.536 & & 11.658 & .000 & 23353.7186 & 33131.468 \\
\hline & $\begin{array}{l}\text { The density } \\
\text { of highways } \\
\left(\mathrm{km} / 1000 \mathrm{~km}^{2}\right)\end{array}$ & 821.526 & 445.751 & .630 & 1.843 & .072 & -78.037 & 1721.089 \\
\hline & $\begin{array}{l}\text { The density } \\
\text { of railways } \\
\left(\mathrm{km} / 1000 \mathrm{~km}^{2}\right)\end{array}$ & -8.552 & 13.751 & -.213 & -.622 & .537 & -36.304 & 19.200 \\
\hline
\end{tabular}

a. Dependent variable: GRP per capita (yuan)

Source: Compiled by authors

Table A4. Estimation of GRP per capita using regression equation a

\begin{tabular}{|c|c|c|c|c|c|c|c|c|c|c|}
\hline \multirow[t]{2}{*}{ Province } & \multirow[t]{2}{*}{ Indicator } & \multicolumn{9}{|c|}{ Case number } \\
\hline & & 1 & 2 & 3 & 4 & 5 & 6 & 7 & 8 & 9 \\
\hline \multirow{4}{*}{ Shaanxi } & $\begin{array}{l}\text { Standard } \\
\text { residual }\end{array}$ & .837 & -1.121 & .888 & -.530 & -.795 & .366 & -.757 & -.156 & 1.269 \\
\hline & $\begin{array}{c}\text { GRP per } \\
\text { capita } \\
\text { (yuan) }\end{array}$ & 21921 & 27104 & 33429 & 38512 & 43054 & 46861 & 47513 & 50877 & 57108 \\
\hline & $\begin{array}{c}\text { Predicted } \\
\text { value }\end{array}$ & 20709.68 & 28726.69 & 32143.42 & 39279.68 & 44204.74 & 46331.83 & 48609.12 & 51103.09 & 55270.77 \\
\hline & Residual & $1.211 \mathrm{E} 3$ & $-1.623 \mathrm{E} 3$ & $1.286 \mathrm{E} 3$ & -767.675 & $-1.151 \mathrm{E} 3$ & 529.173 & $-1.096 \mathrm{E} 3$ & -226.089 & $1.837 \mathrm{E} 3$ \\
\hline \multirow[t]{4}{*}{ Gansu } & $\begin{array}{l}\text { Standard } \\
\text { residual }\end{array}$ & -.500 & -.160 & 1.089 & -.954 & .839 & .572 & -.956 & -.881 & .952 \\
\hline & $\begin{array}{c}\text { GRP per } \\
\text { capita } \\
\text { (yuan) }\end{array}$ & 13259 & 16097 & 19580 & 21917 & 24519 & 26387 & 26117 & 27588 & 28408 \\
\hline & $\begin{array}{c}\text { Predicted } \\
\text { value }\end{array}$ & 13643.26 & 16219.83 & 18742.67 & 22651.01 & 23873.76 & 25947.37 & 26852.43 & 28265.81 & 27675.87 \\
\hline & Residual & -384.257 & -122.825 & 837.332 & -734.007 & 645.236 & 439.633 & -735.431 & -677.810 & 732.129 \\
\hline \multirow[t]{3}{*}{ Qinghai } & $\begin{array}{l}\text { Standard } \\
\text { residual }\end{array}$ & -1.427 & -.499 & .538 & 1.109 & .652 & .722 & .225 & -.255 & -1.064 \\
\hline & $\begin{array}{c}\text { GRP per } \\
\text { capita } \\
\text { (yuan) }\end{array}$ & 19412 & 23986 & 29409 & 33046 & 36714 & 39508 & 41106 & 43381 & 43893 \\
\hline & $\begin{array}{c}\text { Predicted } \\
\text { value }\end{array}$ & 23388.65 & 25377.66 & 27910.12 & 29955.23 & 34898.32 & 37496.51 & 40479.31 & 44090.89 & 46858.32 \\
\hline
\end{tabular}


(C) $L i, A n \mathcal{E} \operatorname{Rim}$

\begin{tabular}{|c|c|c|c|c|c|c|c|c|c|c|}
\hline & Residual & $-3.977 \mathrm{E} 3$ & $-1.392 \mathrm{E} 3$ & $1.499 \mathrm{E} 3$ & 3.091E3 & $1.816 \mathrm{E} 3$ & 2.011E3 & 626.695 & $\begin{array}{c}- \\
3.82138 \mathrm{E} 1 \\
\end{array}$ & $-2.965 \mathrm{E} 3$ \\
\hline \multirow[t]{4}{*}{ Ningxia } & $\begin{array}{l}\text { Standard } \\
\text { residual }\end{array}$ & .487 & -.956 & .194 & .505 & .641 & -.852 & -1.486 & .471 & .995 \\
\hline & $\begin{array}{c}\text { GRP per } \\
\text { capita } \\
\text { (yuan) }\end{array}$ & 21653 & 26693 & 32898 & 36187 & 39412 & 41573 & 43589 & 46942 & 50492 \\
\hline & $\begin{array}{c}\text { Predicted } \\
\text { value }\end{array}$ & 21072.58 & 27832.44 & 32667.12 & 35584.96 & 38648.10 & 42587.96 & 45359.51 & 46380.56 & 49305.76 \\
\hline & Residual & 580.416 & $-1.139 \mathrm{E} 3$ & 230.880 & 602.044 & 763.897 & $-1.015 \mathrm{E} 3$ & $-1.771 \mathrm{E} 3$ & 561.436 & $1.186 \mathrm{E} 3$ \\
\hline \multirow[t]{4}{*}{ Xinjiang } & $\begin{array}{l}\text { Standard } \\
\text { residual }\end{array}$ & -1.483 & -.190 & 1.343 & .282 & .702 & .642 & -.332 & -.929 & -.035 \\
\hline & $\begin{array}{c}\text { GRP per } \\
\text { capita } \\
\text { (yuan) }\end{array}$ & 19810 & 24474 & 29923 & 33611 & 37296 & 40354 & 39512 & 40241 & 44507 \\
\hline & $\begin{array}{c}\text { Predicted } \\
\text { value }\end{array}$ & 23685.44 & 24970.84 & 26413.48 & 32873.75 & 35462.78 & 38676.99 & 40379.06 & 42668.19 & 44597.47 \\
\hline & Residual & $-3.875 \mathrm{E} 3$ & -496.845 & $3.510 \mathrm{E} 3$ & 737.247 & 1.833E3 & 1.677E3 & -867.058 & $-2.427 \mathrm{E} 3$ & -90.467 \\
\hline
\end{tabular}

a Dependent Variable: GRP per capita (yuan)

Source: Compiled by authors

Appendix B: Results of regression analysis (Coastal provinces)

Table B1. Contribution of independent variables to dependent variable ${ }^{b}$

\begin{tabular}{|c|c|c|c|c|}
\hline Model a & $\mathbf{R}$ & $\mathbf{R}^{\mathbf{2}}$ & Adjusted $\mathbf{R}^{2}$ & $\begin{array}{c}\text { The standard error } \\
\text { of estimate }\end{array}$ \\
\hline Fujian & $.997^{\mathrm{a}}$ & .994 & .992 & 1463.642 \\
\hline Guangdong & $.970^{\mathrm{a}}$ & .940 & .921 & 3817.974 \\
\hline Guangxi & $.977^{\mathrm{a}}$ & .955 & .940 & 1865.816 \\
\hline Hainan & $.992^{\mathrm{a}}$ & .984 & .979 & 1391.783 \\
\hline Zhejiang & $.990^{\mathrm{a}}$ & .980 & .973 & 2550.94198 \\
\hline Whole & $.900^{\mathrm{a}}$ & .810 & .801 & 8702.17338 \\
\hline
\end{tabular}

Note: ${ }^{a}$ Predictors: (Constant), the density of railways $\left(\mathrm{km} / 1000 \mathrm{~km}^{2}\right)$, the density of highways $\left(\mathrm{km} / 1000 \mathrm{~km}^{2}\right)$

b. Dependent variable: GRP per capita (yuan)

Source: Compiled by authors 
Business Perspective Review 2(2), 2020

Table B2. Analysis of Variance (ANOVA) b

\begin{tabular}{|c|c|c|c|c|c|c|}
\hline \multicolumn{2}{|c|}{ Model a } & Sum of & Degree of & Mean & $\mathbf{F}$ & Significance \\
\hline Fujian & $\begin{array}{c}\text { Regression } \\
\text { Residual } \\
\text { Total }\end{array}$ & $\begin{array}{l}2.044 \mathrm{E} 9 \\
1.285 \mathrm{E} 7 \\
2.057 \mathrm{E} 9\end{array}$ & $\begin{array}{l}2 \\
6 \\
8\end{array}$ & $\begin{array}{c}1.022 \mathrm{E} 9 \\
2142248.12 \\
8\end{array}$ & 477.051 & $.000^{a}$ \\
\hline Guangdong & $\begin{array}{c}\text { Regression } \\
\text { Residual } \\
\text { Total } \\
\end{array}$ & $\begin{array}{l}1.381 \mathrm{E} 9 \\
8.746 \mathrm{E} 7 \\
1.469 \mathrm{E} 9\end{array}$ & $\begin{array}{l}2 \\
6 \\
8 \\
\end{array}$ & $\begin{array}{l}6.906 \mathrm{E} 8 \\
1.458 \mathrm{E} 7\end{array}$ & 47.376 & $.000^{a}$ \\
\hline Guangxi & $\begin{array}{c}\text { Regression } \\
\text { Residual } \\
\text { Total }\end{array}$ & $\begin{array}{l}4.438 \mathrm{E} 8 \\
2.089 \mathrm{E} 7 \\
4.647 \mathrm{E} 8\end{array}$ & $\begin{array}{l}2 \\
6 \\
8\end{array}$ & $\begin{array}{c}2.219 \mathrm{E} 8 \\
3481268.18 \\
5\end{array}$ & 63.748 & $.000^{\mathrm{a}}$ \\
\hline Hainan & $\begin{array}{c}\text { Regression } \\
\text { Residual } \\
\text { Total } \\
\end{array}$ & $\begin{array}{l}7.163 \mathrm{E} 8 \\
1.162 \mathrm{E} 7 \\
7.279 \mathrm{E} 8\end{array}$ & $\begin{array}{l}2 \\
6 \\
8 \\
\end{array}$ & $\begin{array}{c}3.581 \mathrm{E} 8 \\
1937061.28 \\
7 \\
\end{array}$ & 184.883 & $.000^{a}$ \\
\hline Zhejiang & $\begin{array}{c}\text { Regression } \\
\text { Residual } \\
\text { Total }\end{array}$ & $\begin{array}{l}1.890 \mathrm{E} 9 \\
3.904 \mathrm{E} 7 \\
1.929 \mathrm{E} 9\end{array}$ & $\begin{array}{l}2 \\
6 \\
8\end{array}$ & $\begin{array}{c}9.450 \mathrm{E} 8 \\
6507305.00 \\
4\end{array}$ & 145.229 & $.000^{\mathrm{a}}$ \\
\hline Whole & $\begin{array}{c}\text { Regression } \\
\text { Residual } \\
\text { Total }\end{array}$ & $\begin{array}{c}1.360 \mathrm{E} 10 \\
3.181 \mathrm{E} 9 \\
1.678 \mathrm{E} 10\end{array}$ & $\begin{array}{c}2 \\
42 \\
42\end{array}$ & $\begin{array}{l}6.798 \mathrm{E} 9 \\
7.573 \mathrm{E} 7\end{array}$ & 89.767 & $.000^{a}$ \\
\hline
\end{tabular}

Note: a. Predictors: (Constant), the density of railways $\left(\mathrm{km} / 1000 \mathrm{~km}^{2}\right)$, the density of highways $\left(\mathrm{km} / 1000 \mathrm{~km}^{2}\right)$

b. Dependent variable: GRP per capita (yuan)

Source: Compiled by authors

Table B3. Regression coefficients ${ }^{a}$

\begin{tabular}{|c|c|c|c|c|c|c|c|c|}
\hline \multirow{2}{*}{\multicolumn{2}{|c|}{ Model }} & \multicolumn{2}{|c|}{ Unstandardized Coefficients } & \multirow{2}{*}{\begin{tabular}{|c|} 
Standardized \\
Coefficients \\
Beta \\
\end{tabular}} & \multirow[t]{2}{*}{$\mathbf{t}$} & \multirow[t]{2}{*}{ Significance } & \multicolumn{2}{|c|}{$\begin{array}{l}\text { 95\% Confidence Interval for } \\
\text { B }\end{array}$} \\
\hline & & $\mathrm{B}$ & $\begin{array}{l}\text { Standard } \\
\text { Error }\end{array}$ & & & & Lower Bound & $\begin{array}{l}\text { Upper } \\
\text { Bound }\end{array}$ \\
\hline \multirow[t]{3}{*}{ Fujian } & (Constant) & -305287.744 & 27819.452 & & -10.974 & .000 & -373359.490 & -237215.999 \\
\hline & $\begin{array}{l}\text { The density } \\
\text { of highways } \\
\left(\mathrm{km} / 1000 \mathrm{~km}^{2}\right)\end{array}$ & -4077.242 & 772.236 & -1.037 & -5.280 & .002 & -5966.836 & -2187.649 \\
\hline & $\begin{array}{l}\text { The density } \\
\text { of railways } \\
\left(\mathrm{km} / 1000 \mathrm{~km}^{2}\right)\end{array}$ & 555.590 & 54.411 & 2.005 & 10.211 & .000 & 422.451 & 688.729 \\
\hline
\end{tabular}


(C) $L i, A n \mathcal{E} R i m$

\begin{tabular}{|c|c|c|c|c|c|c|c|c|}
\hline \multirow[t]{3}{*}{ Guangdong } & (Constant) & -233011.691 & 103546.286 & & -2.250 & .065 & -486380.325 & 20356.943 \\
\hline & $\begin{array}{l}\text { The density } \\
\text { of highways } \\
\left(\mathrm{km} / 1000 \mathrm{~km}^{2}\right)\end{array}$ & -2397.334 & 2553.905 & $\begin{array}{c}\cdot \\
-.697\end{array}$ & -.939 & .384 & -8646.513 & 3851.846 \\
\hline & $\begin{array}{l}\text { The density } \\
\text { of railways } \\
\left(\mathrm{km} / 1000 \mathrm{~km}^{2}\right)\end{array}$ & 298.761 & 133.976 & 1.656 & 2.230 & .067 & -29.067 & 626.589 \\
\hline \multirow[t]{3}{*}{ Guangxi } & (Constant) & -93116.614 & 22604.472 & & -4.119 & .006 & -148427.765 & -37805.462 \\
\hline & $\begin{array}{l}\text { The density } \\
\text { of highways } \\
\left(\mathrm{km} / 1000 \mathrm{~km}^{2}\right)\end{array}$ & -647.107 & 599.908 & -.339 & -1.079 & .322 & -2115.029 & 820.815 \\
\hline & $\begin{array}{l}\text { The density } \\
\text { of railways } \\
\left(\mathrm{km} / 1000 \mathrm{~km}^{2}\right)\end{array}$ & 284.868 & 68.998 & 1.299 & 4.129 & .006 & 116.036 & 453.701 \\
\hline \multirow[t]{3}{*}{ Hainan } & (Constant) & -33933.821 & 4526.002 & & -7.498 & .000 & -45008.548 & -22859.093 \\
\hline & $\begin{array}{l}\text { The density } \\
\text { of highways } \\
\left(\mathrm{km} / 1000 \mathrm{~km}^{2}\right)\end{array}$ & 92.498 & 179.114 & .055 & .516 & .624 & -345.779 & 530.775 \\
\hline & $\begin{array}{l}\text { The density } \\
\text { of railways } \\
\left(\mathrm{km} / 1000 \mathrm{~km}^{2}\right)\end{array}$ & 94.130 & 10.584 & .944 & 8.894 & .000 & 68.232 & 120.028 \\
\hline \multirow[t]{3}{*}{ Zhejiang } & (Constant) & -312153.435 & 48226.710 & & -6.473 & .001 & -430159.944 & -194146.926 \\
\hline & $\begin{array}{l}\text { The density } \\
\text { of highways } \\
\left(\mathrm{km} / 1000 \mathrm{~km}^{2}\right)\end{array}$ & 334.860 & 587.070 & .083 & .570 & .589 & -1101.649 & 1771.369 \\
\hline & $\begin{array}{l}\text { The density } \\
\text { of railways } \\
\left(\mathrm{km} / 1000 \mathrm{~km}^{2}\right)\end{array}$ & 331.395 & 52.613 & .913 & 6.299 & .001 & 202.656 & 460.134 \\
\hline \multirow[t]{3}{*}{ Whole } & (Constant) & -28444.344 & 6487.630 & & -4.384 & .000 & -41536.912 & -15351.777 \\
\hline & $\begin{array}{l}\text { The density } \\
\text { of highways } \\
\left(\mathrm{km} / 1000 \mathrm{~km}^{2}\right)\end{array}$ & 1735.011 & 307.100 & .401 & 5.650 & .000 & 1115.258 & 2354.763 \\
\hline & $\begin{array}{l}\text { The density } \\
\text { of railways } \\
\left(\mathrm{km} / 1000 \mathrm{~km}^{2}\right)\end{array}$ & 50.979 & 5.249 & .689 & 9.712 & .000 & 40.386 & 61.572 \\
\hline
\end{tabular}

a. Dependent variable: GRP per capita (yuan)

Source: Compiled by authors 
Table B4. Estimation of GRP per capita using regression equation a

\begin{tabular}{|c|c|c|c|c|c|c|c|c|c|c|}
\hline \multirow[t]{2}{*}{ Province } & \multirow[t]{2}{*}{ Indicator } & \multicolumn{9}{|c|}{ Case number } \\
\hline & & 1 & 2 & 3 & 4 & 5 & 6 & 7 & 8 & 9 \\
\hline \multirow{4}{*}{ Fujian } & $\begin{array}{c}\text { Standard } \\
\text { residual }\end{array}$ & -.270 & -.502 & .420 & 1.174 & -.991 & -.431 & 1.185 & -1.122 & .537 \\
\hline & $\begin{array}{c}\text { GRP per } \\
\text { capita } \\
\text { (yuan) }\end{array}$ & 33378 & 39906 & 47205 & 52566 & 57945 & 63205 & 67673 & 74369 & 82286 \\
\hline & $\begin{array}{c}\text { Predicted } \\
\text { value }\end{array}$ & 33773.44 & 40640.53 & 46590.90 & 50847.46 & 59395.80 & 63836.27 & 65937.89 & 76010.73 & 81499.96 \\
\hline & Residual & -395.444 & -734.534 & 614.099 & $1.719 \mathrm{E} 3$ & $-1.451 \mathrm{E} 3$ & -631.275 & $1.735 \mathrm{E} 3$ & $-1.642 \mathrm{E} 3$ & 786.039 \\
\hline \multirow[t]{4}{*}{ Guangdong } & $\begin{array}{c}\text { Standard } \\
\text { residual }\end{array}$ & -.465 & -.650 & 1.165 & .181 & .404 & -.662 & -1.340 & .119 & 1.249 \\
\hline & $\begin{array}{l}\text { GRP per } \\
\text { capita } \\
\text { (yuan) }\end{array}$ & 38976 & 44070 & 50652 & 53868 & 58695 & 63232 & 67115 & 73511 & 80316 \\
\hline & $\begin{array}{c}\text { Predicted } \\
\text { value }\end{array}$ & 40749.81 & 46552.66 & 46205.03 & 53178.11 & 57153.39 & 65758.47 & 72232.62 & 73058.12 & 75546.80 \\
\hline & Residual & $-1.774 \mathrm{E} 3$ & $-2.483 \mathrm{E} 3$ & 4.447E3 & 689.891 & $1.542 \mathrm{E} 3$ & $-2.526 \mathrm{E} 3$ & $-5.118 \mathrm{E} 3$ & 452.883 & $4.769 \mathrm{E} 3$ \\
\hline \multirow[t]{4}{*}{ Guangxi } & $\begin{array}{c}\text { Standard } \\
\text { residual }\end{array}$ & -1.583 & .290 & .695 & .166 & .574 & .603 & .303 & .361 & -1.409 \\
\hline & $\begin{array}{l}\text { GRP per } \\
\text { capita } \\
\text { (yuan) }\end{array}$ & 15979 & 20759 & 25233 & 27841 & 30621 & 32968 & 35036 & 37862 & 37919 \\
\hline & $\begin{array}{c}\text { Predicted } \\
\text { value } \\
\end{array}$ & 18932.19 & 20218.63 & 23936.16 & 27531.20 & 29549.41 & 31843.02 & 34470.56 & 37189.12 & 40547.71 \\
\hline & Residual & $-2.953 \mathrm{E} 3$ & 540.367 & 1.297E3 & 309.801 & $1.072 \mathrm{E} 3$ & $1.125 \mathrm{E} 3$ & 565.440 & 672.882 & $-2.629 \mathrm{E} 3$ \\
\hline \multirow[t]{4}{*}{ Hainan } & $\begin{array}{c}\text { Standard } \\
\text { residual }\end{array}$ & -.823 & -.366 & -.015 & -.227 & 1.005 & 1.249 & .314 & .386 & -1.523 \\
\hline & $\begin{array}{l}\text { GRP per } \\
\text { capita } \\
\text { (yuan) }\end{array}$ & 19146 & 23757 & 28765 & 32193 & 35503 & 38768 & 40645 & 44201 & 48192 \\
\hline & $\begin{array}{c}\text { Predicted } \\
\text { value } \\
\end{array}$ & 20291.80 & 24266.25 & 28786.35 & 32509.18 & 34104.68 & 37029.28 & 40207.38 & 43663.82 & 50311.25 \\
\hline & Residual & $-1.146 \mathrm{E} 3$ & -509.252 & -21.355 & -316.180 & $1.398 \mathrm{E} 3$ & $1.739 \mathrm{E} 3$ & 437.620 & 537.181 & $-2.119 \mathrm{E} 3$ \\
\hline
\end{tabular}


(C) $L i, A n \mathcal{E} R i m$

\begin{tabular}{|c|c|c|c|c|c|c|c|c|c|c|}
\hline \multirow{7}{*}{ Zhejiang } & $\begin{array}{c}\text { Standard } \\
\text { residual }\end{array}$ & .711 & -.632 & .566 & -.110 & -.558 & -.549 & -1.218 & .163 & 1.625 \\
\cline { 2 - 8 } & $\begin{array}{c}\text { GRP per } \\
\text { capita } \\
\text { (yuan) }\end{array}$ & 43575.34 & 50894.64 & 59159.53 & 63292.55 & 68673.32 & 72935.78 & 77426.41 & 84528.37 & 91511.86 \\
\cline { 2 - 9 } & $\begin{array}{c}\text { Predicted } \\
\text { value }\end{array}$ & 41761.7013 & 52505.6185 & 57715.1526 & 63574.2215 & 70096.2789 & 74335.0697 & 80532.4413 & 84111.5106 & 87365.81 \\
\cline { 2 - 8 } & $\begin{array}{c}\text { Residual } \\
\end{array}$ & $1.81364 \mathrm{E} 3$ & $-1.61098 \mathrm{E} 3$ & $1.44438 \mathrm{E} 3$ & $-2.81671 \mathrm{E} 2$ & $-1.42296 \mathrm{E} 3$ & $-1.39929 \mathrm{E} 3$ & $-3.10603 \mathrm{E} 3$ & $4.16862 \mathrm{E} 2$ & $4.14605 \mathrm{E}$ \\
\end{tabular}

a. Dependent variable: GRP per capita (yuan)

Source: Compiled by authors 